\title{
Effect of Benzylaminopurine, Gibberellic Acid, Silver Nitrate and Silver Thiosulphate, on postharvest longevity of cut leaves of Dracaena
}

\author{
R.M.B. Subhashini ${ }^{1}$, N.L.K.Amarathunga ${ }^{1}$, S.A. Krishnarajah ${ }^{2}$ and J. P. Eeswara ${ }^{1}$ * \\ ${ }^{1}$ Department of Crop Science, Faculty of Agriculture, University of Peradeniya, Peradeniya, Sri Lanka. \\ ${ }^{2}$ Royal Botanic Gardens, Peradeniya, Sri Lanka. \\ Accepted 05 October 2011
}

\begin{abstract}
Leaf yellowing associated with early senescence is a major problem associated with cut decorative leaves and flowers of many tropical plant species. Effect of postharvest application of benzylaminopurine (BAP), gibberellic acid $\left(\mathrm{GA}_{3}\right)$, silver-thiosulphate (STS) and silver nitrate $\left(\mathrm{AgNO}_{3}\right)$ on vase life of cut leaves of three Dracaena species Dracaena marginata 'bi colour', Dracaena sanderiana 'white' and Dracaena deremensis were investigated. Deionized water (DIW) was used as the control. All the BAP treatments $(25,50$ and $100 \mu \mathrm{M})$ applied either as 10 minutes immersion or as $24 \mathrm{~h}$ pulse improved the vase life of all three species examined. Application of STS $(2 \mathrm{mM})$ and $\mathrm{AgNO}_{3}$ ( $10 \mathrm{mM} \mathrm{Ag}$ ions) did not increase the vase life of $D$. marginata 'bi colour' and $D$. sanderiana 'white' significantly while $\mathrm{GA}_{3}(50,100$ and 250 $\mu \mathrm{M}$ ) either as a pulse or immersion, significantly reduced the postharvest life of $D$. deremensis compared to untreated leaves. Results suggest that the application of $25 \mu \mathrm{M}$ BAP as a pulse treatment for $24 \mathrm{~h}$ can be recommended to prolong the postharvest life through delayed leaf senescence and thus enhance the marketability of cut leaves of Dracaena marginata 'bi colour', Dracaena sanderiana 'white' and Dracaena deremensis.
\end{abstract}

Key words: postharvest life, Dracaena marginata 'bi colour', Dracaena sanderiana 'white', Dracaena deremensis, marketability

\section{INTRODUCTION}

Dracaena is a genus of about 40 species of trees and succulent shrubs classified in the family Ruscaceae in the APG II system, or separated (with Cordyline) into a family of their own, Dracaenaceae or in the Agavaceae (Anon., 2011). Some shrubby species, such as Dracaena deremensis, $D$. frgrans, $D$. godseffiana, $D$. marginata and D. sanderiana are popular as houseplants and are used to decorate homes, offices, malls, apartments and the landscape around the world (Anon., 2011). Rooted stem cuttings of $D$. sanderiana are widely marketed in the U.S.A. as "Lucky Bamboo" (Anon., 2011). The demand for shoot-tops of D. marginata and $D$. sanderiana is still increasing in Europe (Ladha, 2011). Sri Lanka has the t potential to supply Dracaena to the European and USA markets due to the climatic conditions favourable for the growth of Dracaena in the country. In order to compete in the international market, exporters must be able to supply good quality plant products on a regular basis and should be able to maintain the quality during the marketing process. Loss of appealing quality

*Corresponding author’s email: jpe@pdn.ac.lk characteristics and rapid desiccation within a short period after detaching from mother plants is one of the major problems in exporting foliage plant species from Sri Lanka (Perera et al., 2009). Detachment of flowers and leaves usually advances the onset of senescence resulting in rapid breakdown of macro molecules including proteins, RNAs and membrane lipids causing an outflow of non-protein nitrogen, lipids and nucleic acid components through the leaky membranes (Arteca, 1996). Loss of chlorophyll which occurs as a result of chloroplast degradation is one of the indicators of the senescence process of cut foliage. The onset of senescence of cut foliage may be induced by various external factors such as temperature, moisture content, gases, radiation and pathogens, while internal factors related to senescence are regulated mainly by two phytohormones, ethylene and abscisic acid (ABA) (Weaver et al., 1998). In contrast, cytokinins delay senescence of cut foliage mainly by maintaining the integrity of the tonoplast membrane and preventing leakage of proteases which hydrolyse the soluble proteins of chloroplast and mitochondrial membranes (Thinmann, 1980). Gibberellins are known to delay senescence by 
preventing the loss of chlorophylls and degradation of RNA and proteins in cut foliage (Arteca, 1996).

Wilting and leaf yellowing are the predominant postharvest problems associated with cut foliage, and use of preservatives has shown to be effective in retarding these processes. Silver nitrate $\left(\mathrm{AgNO}_{3}\right)$ and silver thiosulphate (STS), which interfere the binding sites of ethylene, are the common forms of silver salts used in commercial flower preservative solutions. Pulsing with $\mathrm{AgNO}_{3}$ has reported to enhance the vase life of roses (Singh and Tewari, 2002; Darras et al., 2010; Elgimabi, 2011) and Anthuriums (Paull and Goo, 1982) by interfering with ethylene binding. Silver ions delay senescence not only through inhibiting the ethylene binding, but also through acting as a biocide thus eliminating the microbial blockage of the xylem vessels and maintaining the hydraulic conductivity of the stems (Ohkawa et al., 1999; Ichimura. 2003).

External supply of cytokinins and gibberellins has also been reported to reduce leaf chlorosis and yellowing in several cut foliage and flower species (Skutinik et al., 2001, Ranwala et al., 2003, Mutui et al., 2006, Singh et al., 2008). However, the efficiency of plant growth regulators (PGRs) in delaying senescence and enhancing postharvest life depends on the plant species used (Paull and Chantrachit, 2001), type and concentration of preservative solution and the method of application (Ranwala et al., 2003).

The present study was carried out to identify suitable postharvest treatments that would enhance the vase life of cut foliage of three Dracaena species; D. marginata 'Bi colour', $D$. sanderiana 'White' and D. deremensis.

\section{MATERIALS AND METHODS}

\section{Plant materials and laboratory procedures}

Top cuttings of D. marginata 'Bi colour' and $D$. sanderiana 'White' shoots were harvested from a commercial farm at Kalagedihena while top cuttings of $D$. deremensis were obtained from plants grown in a net-house in the Royal Botanic Garden at Peradeniya, Sri Lanka. Harvesting of leaves was done between 07.00-08.00 am. Their cut ends were immersed in deionized water (DIW) and the rest of the parts were covered with plastic bags. Cut leaves were transported to the laboratory within $2 \mathrm{~h}$ of harvesting. The cuttings were graded for uniformity and stems were recut under DIW using sterile, sharp scalpels.
Different treatment solutions were prepared with Benzylaminopurin (BAP, Sigma-Aldrich, USA), gibberellic acid $\left(\mathrm{GA}_{3}-\right.$ Sigma-Aldrich, USA), silver nitrate $\left(\mathrm{AgNO}_{3}\right.$-Sigma-Aldrich, USA) and sodium thiosulphate $\left(\mathrm{Na}_{2} \mathrm{~S}_{2} \mathrm{O}_{3}\right)$. . Silver thiosulphate complex (STS) was prepared according to Sigma-Aldrich, USA catalogue (Sigma Aldrich, 2010). Freshly prepared solutions were used in all experiments. Glass jars $(375 \mathrm{ml})$ autoclaved at $120^{\circ} \mathrm{C}$ and $15 \mathrm{psi}$ were used for the vase life experiments. Experiments were conducted in an airconditioned room $\left(22 \pm 1^{\circ} \mathrm{C}\right)$ under $70-80 \%$ relative humidity $(\mathrm{RH})$ with an average radiation of about $20 \mu \mathrm{mol} \mathrm{m}^{-1} \mathrm{~s}^{-1}$ for $12 \mathrm{~h}$ per day.

Effect of Benzylaminopurine, Silver Nitrate and Silver thiosulphate, on Postharvest life of D. marginata 'Bi colour' and $D$. sanderiana 'White' cut leaves

This experiment was conducted with the objective of identifying the most effective concentration of selected ethylene-binding inhibitor chemical or PGR for lengthening the vase life of Dracaena top cuttings. The effect of STS (2 mM), $\mathrm{AgNO}_{3}$ (1000 ppm or approx 10 $\mathrm{mM} \mathrm{Ag}$ ions), and BAP $(25,50,100 \mu \mathrm{M})$ on vase life of cut leaves of $D$. marginata ' $\mathrm{Bi}$ colour' and D. sanderiana 'white' were investigated. Top shoot cuttings were immersed in each of $200 \mathrm{ml} \mathrm{STS}, \mathrm{AgNO}_{3}$, and BAP solutions for 10 minutes. Thereafter, cuttings were transferred into glass jars containing 200 $\mathrm{ml}$ de-ionized water (DIW). Untreated leaves were placed directly in DIW as the control. The mouths of jars were covered around the stem, with Parafilm (Pechiney Plastic Packaging, Chicago, IL, USA) to prevent evaporation and contamination. DIW in jars was replaced with fresh DIW at 5 day intervals.

Effect of BAP, and $\mathrm{GA}_{3}$ concentrations and method of application on vase life of $D$. deremensis

Effects of BAP $(25,50,100 \mu \mathrm{M})$, and $\mathrm{GA}_{3}(50$, $100,250 \mu \mathrm{M})$ concentrations and two methods of applications on vase life of cut leaves of $D$. deremensis was investigated. Cut leaves were placed in sterile glass jars containing $200 \mathrm{ml}$ of treatment solutions and the treatments applied using two methods, viz. pulse conditioning (by placing shoots of top cuttings for $24 \mathrm{~h}$ in PGR solutions) or immersion (by immersing cuttings for 10 mins in PGR solutions). Untreated leaves placed directly into DIW were used as control. After treatment, leaves were transferred into glass jars containing $200 \mathrm{ml}$ of DIW and 
covered, as described previously. DIW in jars was replaced with fresh DIW at 5 day intervals.

\section{Foliage evaluation}

Treated shoot cuttings were evaluated by ranking the colour of leaves according to a selfprepared scale for colour of leaves (fresh looking leaves-3; slightly pale in colour-2; moderately yellow-1, severely yellow-0), for visual condition of leaves (no blemishes-3, slightly brown tips and margins-2; dry and brown tips and margins-1; leaf blade brown -0) and for petiole condition (straight, fresh stem-4; slight brown and bent-3; moderately brown and bent-2, severely brown and bent-1 and dry petioles -0). Vase life of Dracaena was determined as the number of days taken for change in the colour of leaves from rank 3 to 2 , visual condition from rank 3 to 2 and petiole condition from rank 4 to 3 . The overall vase life was set as the day on which the leaves obtained an aggregate value of 7 for colour of leaves, visual condition and petiole condition.

\section{Experimental design and data analysis}

The both experiments were arranged in complete randomized design. Each treatment consisted of 3 replicates and each replicate consisted of 5 top cuttings. The data were subjected to analysis of variance (ANOVA) using the General Linear Model (GLM) (SAS Institute, Cary, NC, USA). Treatment means were compared by the Duncan's New Multiple Range Test (DNMRT) at $5 \%$ probability level.

\section{RESULTS}

Experimental findings revealed that immersion of cut leaves of $D$. marginata 'bi colour' and $D$. sanderiana 'white' either in STS or $\mathrm{AgNO}_{3}$ for $10 \mathrm{~min}$ had no effect on prolonging the vase life in comparison to untreated leaves (Table 1). All the BAP treatments (immersion in 25, 50, 100 $\mu \mathrm{M}$ BAP solutions for $10 \mathrm{~min}$ ) significantly improved the vase life of the two Dracaena species of by 2-5 days compared to the control and, no significant differences among the BAP treatments were observed (Table 1).

Furthermore, both D. marginata 'bi colour' and $D$. sanderiana 'white' leaves showed similar changes in vase life with respect to all the treatments. . Even though, treatment with BAP showed slight improvement (2-5 days) in vase life of $D$. marginata 'bi colour' and $D$. sanderiana 'white', it was decided to conduct further investigations to prolong the vase life using two different plant growth regulators $\left(\mathrm{GA}_{3}\right.$ and BAP) and two different application methods

Application of BAP $(25,50,100 \mu \mathrm{M})$ improved the vase life of $D$. deremensis (Table 2). Pulsing with BAP was more effective than immersion in the same solutions for $10 \mathrm{~min}$, in extending the vase life (by 1.7-fold at $\mathrm{p}=0.05$ ) of $D$. deremensis cut foliage. When $D$. deremensis leaves were pulse-treated either with $25 \mu \mathrm{M}$ and $50 \mu \mathrm{M}$ BAP, vase life increased by 1.7-fold (30.9 and 30.19 days respectively) compared to untreated leaves (18.3 days), thereby extending the vase life of $D$. deremensis significantly.

Application of $\mathrm{GA}_{3}$ significantly reduced the vase life of $D$. deremensis cut foliage. Furthermore, exposure to higher concentrations of $\mathrm{GA}_{3}(100$ and $250 \mu \mathrm{M})$ for a longer duration (24 h pulsing) significantly reduced the vase life of $D$. deremensis leaves compared to low concentration of $\mathrm{GA}_{3}(50 \mu \mathrm{M})$ and higher concentrations of $\mathrm{GA}_{3}(100$ and $250 \mu \mathrm{M})$ for shorter durations (10 min immersion) (Table 2), inferring that the type of preservative and the method of application is of prime importance for a given cut foliage species.

Table 1. Effect of STS, $\mathrm{AgNO}_{3}$, and BAP on vase life of D. marginata 'bi colour' and D. sanderiana 'white'

\begin{tabular}{|c|c|c|c|c|}
\hline \multirow[t]{2}{*}{ Treatments } & \multicolumn{4}{|c|}{ Vase Life (Days) } \\
\hline & \multicolumn{2}{|c|}{ D. marginata 'bi colour', } & \multicolumn{2}{|c|}{ D. sanderiana 'white' } \\
\hline Control (DIW) & $17.5 \pm 1.5$ & $a^{*}$ & $19.0 \pm 1.9$ & $a^{*}$ \\
\hline $\operatorname{STS}(2 \mathrm{mM})$ & $18.5 \pm 0.9$ & $\mathrm{a}$ & $19.8 \pm 1.2$ & $\mathrm{a}$ \\
\hline $\mathrm{AgNO}_{3}(10 \mathrm{mM})$ & $18.8 \pm 0.7$ & $\mathrm{a}$ & $18.3 \pm 1.5$ & $\mathrm{a}$ \\
\hline $\mathrm{BAP}(25 \mu \mathrm{M})$ & $20.9 \pm 0.9$ & $\mathrm{~b}$ & $21.5 \pm 1.3$ & $\mathrm{~b}$ \\
\hline $\mathrm{BAP}(50 \mu \mathrm{M})$ & $21.5 \pm 1.3$ & $\mathrm{~b}$ & $22.5 \pm 0.9$ & $\mathrm{~b}$ \\
\hline $\operatorname{BAP}(100 \mu \mathrm{M})$ & $22.6 \pm 1.5$ & $\mathrm{~b}$ & $22.8 \pm 1.8$ & $\mathrm{~b}$ \\
\hline LSD & 1.35 & & 1.15 & \\
\hline
\end{tabular}

*Values in each column followed by the same letter are not significantly different at $\mathrm{p}=0.05$ 
Table 2. Effect of BAP and GA3 on vase life of D. deremensis cut leaves.

\begin{tabular}{|c|c|c|}
\hline Treatment & Vase life (Days) & $\begin{array}{l}\text { Increase in vase life times }(\mathbf{x}) \\
\text { (Vase life of treatment/ Vase life of } \\
\text { control) }\end{array}$ \\
\hline \multicolumn{3}{|l|}{ Immersion for 10 minutes } \\
\hline BAP $(25 \mu \mathrm{M})$ & $19.13 \pm 1.95 \mathrm{c}$ & 1.05 \\
\hline $\mathrm{BAP}(50 \mu \mathrm{M})$ & $19.73 \pm 1.63 \mathrm{c}$ & 1.08 \\
\hline $\operatorname{BAP}(100 \mu \mathrm{M})$ & $19.39 \pm 1.35 \mathrm{c}$ & 1.06 \\
\hline $\mathrm{GA}_{3}(50 \mu \mathrm{M})$ & $16.66 \pm 1.25 \mathrm{~d}$ & 0.91 \\
\hline $\mathrm{GA}_{3}(100 \mu \mathrm{M})$ & $14.53 \pm 1.32 \mathrm{e}$ & 0.79 \\
\hline $\mathrm{GA}_{3}(250 \mu \mathrm{M})$ & $13.67 \pm 1.64 \mathrm{e}$ & 0.75 \\
\hline \multicolumn{3}{|l|}{ Pulsing for 24 hours } \\
\hline $\mathrm{BAP}(25 \mu \mathrm{M})$ & $30.94 \pm 2.45 \mathrm{a}$ & 1.69 \\
\hline $\mathrm{BAP}(50 \mu \mathrm{M})$ & $30.19 \pm 2.35 \mathrm{a}$ & 1.65 \\
\hline $\operatorname{BAP}(100 \mu \mathrm{M})$ & $24.53 \pm 1,95 b$ & 1.34 \\
\hline $\mathrm{GA}_{3}(50 \mu \mathrm{M})$ & $16.26 \pm 1.45 \mathrm{~d}$ & 0.89 \\
\hline $\mathrm{GA}_{3}(100 \mu \mathrm{M})$ & $11.39 \pm 1.32 \mathrm{f}$ & 0.62 \\
\hline $\mathrm{GA}_{3}(250 \mu \mathrm{M})$ & $10.53 \mathrm{f} \pm 1.52 \mathrm{f}$ & 0.58 \\
\hline Control (De ionized water) & $18.33 \pm 1.65 \mathrm{c}$ & 1.00 \\
\hline LSD & 1.62 & \\
\hline
\end{tabular}

*Values in each column followed by the same letter are not significantly different at $\mathrm{p}=0.05$

\section{DISCUSSION}

Silver nitrate and STS are the most common forms of silver ions used in prolonging the postharvest life of cut flowers and foliage. Inclusion of silver ions in the vase solutions has shown to prolong the vase life of Anthuriums (Paull and Goo, 1982), flowers of Matthiola incana (Celikel and Reid, 2002), cut tuberose flowers (Hutchinson et al., 2003) and roses (Singh and Tewari, 2002, Elgimabi, 2011). In contrast, application of $1000 \mathrm{ppm} \mathrm{AgNO}_{3}$ (approx $10 \mathrm{mM}$ silver ions) and $2 \mathrm{mM}$ STS had no effect on the vase life of $D$. marginata 'bi colour' and D. sanderiana 'white'. Silver ions prolong the vase life of cut flowers and foliage by acting as potent inhibitors of ethylene action inside plant tissues (Paul and Goo, 1982, Elgimabi, 2011). Ethylene does not appear to play a significant role in the senescence process in cut Dracaena foliage. The findings of this study are in agreement with Van Doorn et al., (2011) where ethylene has not shown any effect on tepal abscission in tulips. Plants are classified into 4 groups based on their sensitivity to ethylene and the endogenous production of ethylene; as sensitive plants that produce a high amount of ethylene, sensitive plants that produce a low amount of ethylene, insensitive plants that produce a low amount of ethylene and insensitive plants that produce a high amount of ethylene (Ferrante and Francini, 2006). Thus, it is likely that $D$. marginata 'bi colour' and $D$. sanderiana 'white' are insensitive to ethylene and therefore, silver ions had no effect on prolonging the vase life of these two species.

Benzylaminopurin at low concentrations (25 $\mu \mathrm{M})$ improved the vase life of all three Dracaena species examined. Cytokin has shown to increase the vase life of cut ornamental leaves of Hosta plantiagena (Skutnik et al., 1999), anthuriums (Paul and Goo, 1982), Heliconia psittacorum cv 'Andromeda' (Paull and Chantrachit, 2001), cut flowers of Alstromaria (Dai and Paul, 1991) and Tuberoses (Hutchinson et al., 2003). Cytokinins are known to retard senescence of detached leaves and flowers by delaying proteolysis and chlorophyll degradation (Gan and Amasino. 1997; Winger et al., 1998). The loss of decorative value observed in Dracaena leaves could be mainly attributed to changes in colour. Thus delayed senescence of cut Dracaena leaves may have resulted from BAP-mediated delay in chlorophyll degradation.

Reduction in the postharvest life of $D$. Deremensis with the application of $\mathrm{GA}_{3}$, is in agreement with Cywinska-Smoter et al., (1978) who reported a decrease the longevity and flower and leaf discoloration in carnation and with (Garibaldi and Deamborgia (1988), who showed that gibberellins have no effect on vase life of Chrysanthemum Doi and Reid, (1995) with hybrid Limonium and Hutchinson et al., (2003) with cut Tuberose flowers. In contrast to the findings of the present study, Gibberellins $\left(\mathrm{GA}_{3}\right)$ had shown to delay leaf yellowing in 
Alstroemeria (Dai and Paull, 1991; Muti et al., 2006) and in Easter Lily (Han, 1995; Han, 1997; Ranwala and Miller 1999; Ranwala et al., 2003). These indicate that the plant growth regulators have variable effects on the postharvest quality of different plant species (Bosse and Van Staden, 1989). It is not known what causes the variable effects of gibberellins. One possibility is that exogenous application of synthetic plant growth regulators may alter the natural equilibrium of endogenous growth regulators inducing a stress depending on the plant species and the organ under investigation (Ferrante and Francini, 2006).

Results of the present study suggest that the application of BAP retarded senescence and prolong the vase life of cut foliage of of $D$. marginata 'bi colour', D. sanderiana 'white' and D. deremensis. Pulsing with $25 \mu \mathrm{M}$ BAP for 24 $\mathrm{h}$ can be recommended as a postharvest treatment to preserve the postharvest quality of cut foliage of of $D$. marginata 'bi colour', $D$. sanderiana 'white' and $D$. deremensis during the marketing process.

\section{REFERENCES}

Anonymous (2011). Dracaena Plant. http://www.bookrags.com/wiki/Dracaena_(pla nt). Cited on 14th June2011

Arteca, R.N. (1996). Plant growth substances principles and application. Chapman and Hall, New York.

Bosse, A. \& Van Staden, J. (1989). Cytokinins in cut carnation flowers. Effect of cytokinin type, and mode of application on flower longevity. Journal of Plant Physiology 135: 155-159.

Celikel F.G. And Reid M.S. (2002). Postharvesr handling of stock (Matthiola incana). Hort. Science 37(1): 144-147.

Cywinska-Smoter, K. Rudnicki R.M. and Goszczynska, D. (1978). The effect of exogenous regulation in opening tight carnation buds. Scientia Horticulturae 9: 155165.

Darras, A., Loannidou, A., and Pompodakis, N. (2010). Evaluation and improvement of postharvest performance of cut Viburmum tinus inflorescence. Scientia Horticulturae 124: 376-380.

Dai, J.W. and Paull, R.E. (1991). Postharvest handling of Alstroemeria. Hort. Science 26: 314.

Doi, M. and Reid, M.S. (1995). Sugar improves the postharvest life of cut flowers of hybrid Limonium. Hort. science 30: 1058-1060.
Elgimabi, M.E.N.E. (2011). Vase life extension of Rose cut flowers (Rosa Hybrida) as influenced by silver nitrate and sucrose pulsing. American Journal of Agricultural and Biological Sciences 6(1): 128-133.

Gan, S. and Amasino, R.M. (1997). Making sense of senescence. Molecular genetics regulation and manipulation of leaf senescence. Plant Physiology 113: 313-319.

Garibaldi. E.A. and Deamborgia, F. (1988). Extending the life of cut flowers of Chrysanthemum 'marquerite'. Plant Growth Regulation Abstracts 14: 2445

Ferrante, A. And Francini, A. (2006). Ethylene and leaf senescence. In: Khan N.A. (Ed.), Ethylene action in plant Springer Verlarg, Berlin, Heideberg. Pp 51-64.

Han, S.S. (1995). Growth regulators delay foliar chlorosis of Easter lily leaves. Journal of American Horticultural Science 120(2): 254258.

Han, S.S. (1997). Preventing postproduction leaf yellowing of Easter lily. Journal of American Horticultural Science 122(6): 869-872.

Hutchinson, M.J., Chebet, D.K. and Emongor V.E. (2003). Effect of Accel, sucrose and silver thiosulphate on the water relation and postharvest physiology of cut Tuberose flowers. African Crop Science Journal 11(4): 279-287.

Ichimura, K. (2003). Shortage of soluble carbohydrates is largely responsible for short vase life of cut 'Sonia' rose flowers. Journal of Japanese Society of Horticultural Science 72: $292-298$

Ladha, S. (2011). Floriculture: International Markets. Floriculture Today Magazine, http://floriculturetoday.in/floricultureinternational-markets.html. Cited on 24th May 2011.

Mutui, T.M., Emnogor, V.E. and Hutchinson, M.J. (2006). The effects of gibberellins ${ }_{(4+7)}$ on the vase life and flower quality of Alstroemeria cut flowers. Plant growth regulation 48: 207-214.

Ohkawa, K., Kushhara, Y. and Suh, J.N. (1999). Mobility and effects on vase life of silvercontaining compounds in cut rose flowers. Hortscience 34: 112-113.

Paull, R.E. and Goo, T.T.C. (1982). Pulse treatment with silver nitrate extend the vase life of Anthurium. Journal of American society of Horticultural Science 107: 842-844.

Paull, R.E. and Chantrachit, T. (2001). Benzyladenine and the vase life of tropical ornamentals. Postharvest Biology and Technology 21: 303-310. 
Perera, L.N.S, Daundasekara, W.A.M. and Wijesundara, D.S.A. (2009). Maturity at Harvest affects postharvest longevity of cut Calathea Foliage. Ceylon Journal of Science (Biological Sciences) 38(2): 35-38

Ranwala, A.P., and Miller, W.B. (1999). Timing of gibberellins $(4+7)+$ benzyladenine sprays influences efficacy against foliar chlorosis and plant height in Easter lily. Hort. Science 34: 902-903.

Ranwala, A.P., Legnani G. and Miller, W.B. (2003). Minimizing stem elongation during spray application of gibberellins $(4+7)+$ benzyladenine to prevent leaf chlorosis in Easter lily. Hort. Science 38: 1210-1213.

Sigma Aldrich, (2010). Plant Tissue Culture Protocols, Silver Tiosulfate http://www. sigmaaldrich. Com / life - science / molecular - biology / plant - biotechnology / tissueculture - protocols / silver - thiosulfate . html. Cited on $4^{\text {th }}$ October 2011.

Singh, A.K. and Tewari, A.K. (2002). Effect of pulsing on postharvest life of Rose cv. Doris Tystermann. South Indian Horticulture, 50(13): 140-144.

Singh, A., Kumar, J. and Kumar, P. (2008). Effect of plant growth regulators and sucrose on postharvest physiology, membrane stability and vase life of cut spikes of gladiolus. Plant growth Regulation 55: 221-229.
Skutinik, E., Lukaszewska, A., and Tyborowska, K. (1999). Retarding senescence of cut leaves of Hosta plantaginea by growth regulators. Annals of Warsaw Agricultural University, No. 20. Pp. 3-8.

Skutinik, E., Lukaszewska, A., Serek, M. and Rabiza, J. (2001). Effect of growth regulators on postharvest characteristics of Zantedeschia aethiopica. Postharvest Biology and Technology 21: 241-246.

Thinmann, K.V. (1980). The senescence of leaves. Thinmann K.V. (Ed.), Senescence in Plants. CRC Press, Boca Raton, Florida.

Van Doorn, W.G., Perik, R.R.J., Abadie, P. And Harkema, H, (2011). A treatment to improve the vast life of cut tulips: Effects on tepal senescence, tepal abscission, leaf yellowing and stem elongation. Postharvest Biology and Technology 61: 56-63.

Weaver, L.M., Gan, S., Quirino, B. and Amasino, R.M. (1998). A comparison of the expression patterns of several senescence associated genes in response to stress and hormone treatments. Plant Molecular Biology 37: 455-469.

Winger, A., Von Schaewen, A., Leegood, R.C., Lea, P.J. and Quick, W.P. (1998). Regulation of leaf senescence by cytokinin, sugar and light. Plant Physiology 116: 329-335. 